\title{
Consumption Decision and Influencing Factors of Guilin Tourism Performing Arts Brand-A Case of Ancient Love
}

\author{
Jingyuan Cui1 ${ }^{1}$, Sarana Photchanachan ${ }^{2}$ \\ ${ }^{1} \mathrm{PhD}$ Candidate, School of Management, Shinawatra University, Bangkok, Thailand \\ ${ }^{2}$ Associate Dean, Academic Affairs, School of Management, Shinawatra University, Bangkok, Thailand \\ Email: 34405037ccbb@163.com, sarana.p@siu.ac.th
}

How to cite this paper: Cui, J. Y., \& Photchanachan, S. (2021). Consumption Decision and Influencing Factors of Guilin Tourism Performing Arts Brand-A Case of Ancient Love. Modern Economy, 12, 215-226.

https://doi.org/10.4236/me.2021.121011

Received: November 10, 2020

Accepted: January 26, 2021

Published: January 29, 2021

Copyright $\odot 2021$ by author(s) and Scientific Research Publishing Inc. This work is licensed under the Creative Commons Attribution International License (CC BY 4.0).

http://creativecommons.org/licenses/by/4.0/

\begin{abstract}
The purpose of this study was to find out the factors influencing the purchase intention of tourism performing arts consumers, enhancing the market competitiveness of tourism performing arts products, and enhancing the market share of enterprises. This study has taken the Ancient Love of Guilin as an example to explore the consumption characteristics and influencing factors of tourism performing arts by using a quantitative research method. Using a questionnaire to collect data from 400 consumers who have watched the show for ages. SPSS was used to conduct reliability and validity tests, descriptive analysis, T-test, one-way Anova and regression analysis on the first data of the questionnaire to test the samples. The results showed that brand equity (brand awareness, perceived quality and brand loyalty) has a significant impact on the purchase intention of tourism performing arts consumers. This meant that consumers' purchase intention to travel performing arts could be explained by brand awareness, perceived quality and brand loyalty.
\end{abstract}

\section{Keywords}

Tourism Performing Arts, Guilin, Consumption Characteristics, Factors Affecting, Ancient Love

\section{Introduction}

In the 21st century, the global cultural industry has continued to show a booming trend. Wu (2012) said that "understanding nationality, culture and life style" is one of the three motivations for tourism. Due to the large population and the slow development of tourist attractions in China, most domestic tourism is still 
mainly sightseeing Tours. And the nature of sightseeing tour determines that the tourists will go after a quick tour and climb the mountain. How to stay overnight guests, strive for more secondary consumption, has become a major topic of each scenic spot. With the gradual prosperity of material life, people's spiritual pursuit also began to increase, artistic resources as the object of cultural activities, the combination of folk music and culture has become a part of cultural consumption, tourism performing arts followed. Tourism performing art is part of the solution to this problem. It is mostly performed in the evening, which improves the old tourism consumption pattern of "sightseeing in the day and sleeping at night" in the past, infusing new vitality into the tourism development and giving tourists a unique scenery to see at night (Gong, 2011). Extended the travel time, expanded the tourism format, directly pull the night accommodation and various related needs. Pan \& $\mathrm{Li}$ (2018) believe that tourism performing arts can not only promote the development of local economy by extending tourists' stay time, but also promote the cultural inheritance, innovation and development of folk music culture, and enhance the local cultural image and other cultural and social functions.

According to the statistics of Pricewaterhousecoopers, in 2014, there were 60,200 performances by Chinese tourism performing arts, with box office revenue of 3.837 billion yuan; In 2015, 55,200 performances were performed, with a box office revenue of 3.517 billion yuan, down $8.31 \%$ year-on-year, while 52,900 performances were performed in 2016, with a box office revenue of 3.404 billion yuan, down $4.17 \%$ year-on-year. The total number of tourist performances in 2019 reached 306, and the box office revenue of tourist performances reached 5.908 billion yuan. By June 2019, more than 25 new tourist performances have been added, and the number is expected to exceed 40 throughout the year. The famous performance series continue to expand. In 2018, two performances have been added to the "Ancient of Guilin" and "Eternal Love of the Moon", and the "Legend" of Camel Bell has been added to the "Legend" series of Chinese Literary Travel, further strengthening the performance brand series. With its good brand awareness, it has brought a wide range of customer aggregation effect for the enterprise (China National Tourism Administration, 2017). But on the contrary, in 2018, the tourism and performing arts market shut down or removed 14 plays, and many tourism and performing arts companies went bankrupt one after another. Actually, after the year of 2017, as the tourism performing arts formed the surplus products, and increased the tourists the huge losses, many unknown brands, such as Zhang Jiajie, HenanYuntai mountain folk performing arts company and bankruptcy, proving that the rapid brand aging, low consumer purchase intention, eliminating the high brand, brand can play a role in the market (China Tourism Performance Market, 2019). Consumers are the main body of market consumption. The polarization of the tourism and performing arts market makes researchers have to think about the factors that affect consumers' purchase of tourism and performing arts products. After consulting re- 
levant literature, the research on tourism performing arts in various countries around the world is mainly based on authenticity, protection and inheritance of traditional culture, function of performing arts, future development path and impact on tourism destinations. The specific research on the affecting factors of consumer purchase intention on tourism performing arts brand has not been fully carried out, this is a research gap.

\section{Research Problems and Research Objectives}

Based on the foregoing analysis, the researcher presented the following research questions:

1) What differences do demographic factors affect consumers' purchase intentions?

2) Which factors in the brand equity affect the consumer's purchase intention of tourism performing arts brand products?

3) How to improve the purchase intention of tourism performing arts consumers?

The purposes of the research question are:

1) To find out the difference of consumers purchase intention based on the demographic factors of tourism performing arts customers, and determines the target consumers.

2) To study the affecting factors in brand equity on purchase intention of consumer's tourism performing arts brands. The purpose is to improve brand value, enhance brand market competitiveness, and find ways to increase profit.

3) To investigate the consumers' purchase intention of tourism performing arts .

\section{Materials and Methods}

\subsection{Hypothesis and Conceptual Framwork}

The hypothesis and framework of the study are based on past studies of the purchase intention of tourism performing arts consumers (see Table 1 below).

As can be seen from Table 1: purchase intention was an important dependent variable (Kotler, 2002). Brand equity was the most important factor influencing consumers' purchase intention (Keller, 2001). Etzel et al. (2006) believed that consumers' purchase intention was related to demographic factors. So, brand equtity and demographic factors have a significant impact on consumers' purchase intention.

Measurement of variables is an important part of exploring the relationship between variables. The dimensional measurement of variables is shown in Table 2.

This research adopts the quantitative research method to measure consumers' purchase intention, and extends the research results to cities or regions with tourism performing arts. Based on the literature review in Table 1 and Table 2, the following hypotheses are proposed:

H1: There are significant differences on consumer with different demographic 
Table 1. Past studies on the relationship between independent variables and dependent variable.

\begin{tabular}{|c|c|c|}
\hline Authors & Factors & Finding \\
\hline $\begin{array}{l}\text { Aaker D. A. } \\
(2009)\end{array}$ & $\begin{array}{l}\text { Relationship between } \\
\text { brand entity and } \\
\text { purchase intention }\end{array}$ & $\begin{array}{l}\text { Researchers discovered the brand equity } \\
\text { component; Brand awareness, perceived } \\
\text { quality, brand association and brand loyalty } \\
\text { are positively related to consumer decisions, } \\
\text { especially brand awareness }\end{array}$ \\
\hline $\begin{array}{l}\text { Fouladivanda et al. } \\
\text { (2013) }\end{array}$ & $\begin{array}{l}\text { Relationship between } \\
\text { brand entity and } \\
\text { purchase intention }\end{array}$ & $\begin{array}{l}150 \text { valid questionnaires were absorbed. The } \\
\text { sample size was small, and the measured } \\
\text { result indicated that brand equity had the } \\
\text { greatest influence on purchase intention. }\end{array}$ \\
\hline $\begin{array}{l}\text { Alhadid, A. Y. } \\
\text { (2014) }\end{array}$ & $\begin{array}{l}\text { Brand Equity on Purchase } \\
\text { Intention and } \\
\text { Development. }\end{array}$ & $\begin{array}{l}\text { Brand preference and product price have } \\
\text { influence on consumers' purchase intention, } \\
\text { while brand equity has positive influence on } \\
\text { purchase intention }\end{array}$ \\
\hline $\begin{array}{l}\text { Meena \& Vishnu } \\
\text { (2018) }\end{array}$ & $\begin{array}{l}\text { Brand equity and } \\
\text { customer behavioral } \\
\text { intentions: }\end{array}$ & $\begin{array}{l}\text { The age, education level and gender of } \\
\text { customers have significant influence on } \\
\text { purchase intention. }\end{array}$ \\
\hline $\begin{array}{l}\text { Song \& Li } \\
(2019)\end{array}$ & $\begin{array}{l}\text { Tourism performing arts } \\
\text { marketing }\end{array}$ & $\begin{array}{l}\text { Population is positively correlated with } \\
\text { purchase intention and purchase behavior, } \\
\text { among which high-income tourists are in } \\
\text { the majority. 2) Marketing effect of tourism } \\
\text { performance products is positively } \\
\text { correlated with tourists' recommendation } \\
\text { intention, return visit intention and } \\
\text { satisfaction. }\end{array}$ \\
\hline
\end{tabular}

Source: Authors, adopted from various sources.

Table 2. Dimensions of variable.

\begin{tabular}{cclc}
\hline Type & Name & \multicolumn{1}{c}{ Dimension of Variable } & Authors \\
\hline \multirow{2}{*}{$\begin{array}{c}\text { Bndependent } \\
\text { Variable }\end{array}$} & Brand Equity & $\begin{array}{l}\text { three dimensions: perceived } \\
\text { quality, brand loyalty and } \\
\text { brand awareness. }\end{array}$ & Yoo et al. (2001) \\
& Demographic & $\begin{array}{l}\text { age, gender, education, } \\
\text { profession and income }\end{array}$ & Etzel et al. (2006) \\
Dependent & Factors & Purchase & customer satisfaction, purchase \\
Variable & Intention & intention and recommendation. & Yang \& Liu (2000) \\
\hline
\end{tabular}

Source: Authors, adopted from various sources.

factors of tourism performing arts.

H1a: There is a significant difference on consumers' purchase intention with different gender of tourism performing arts.

H1b: There is a significant difference on consumers' purchase intention with different age of tourism performing arts.

H1c: There is a significant difference on consumers' purchase intention with different educational level of tourism performing arts.

H1d: There is a significant difference on consumers' purchase intention with 
different Personal monthly income of tourism performing arts.

H1e: There is a significant difference on consumers' purchase intention with different Profession of tourism performing arts.

$\mathrm{H} 2$ : There is a significant relationship between brand equity and consumers' purchase intention of tourism performing arts.

H2a: There is a significant relationship between Perceived quality and consumers' purchase intention of tourism performing arts.

H2b: There is a significant relationship between brand loyalty and consumers' purchase intention of tourism performing arts.

$\mathrm{H} 2 \mathrm{c}$ : There is a significant relationship between brand awareness and consumers' purchase intention of tourism performing arts.

These hypotheses were converted to null format for formal testing. They may be represented by the conceptual framework (see Figure 1 below). The purpose of this study is to explore the affecting factors of tourism performing arts brand on consumers' purchase intention Therefore, the author will propose following conceptual framework:

\subsection{Population}

The target population of this study is tourists who have watched the Ancient love in Guilin. Tourism performance is a cultural product. Consumers who have watched it can more accurately express their feelings, especially those who have watched the same type of performance for many times. Therefore, the population in this study was limited to tourists who had attended tourist performances.

\subsection{Sample}

This paper takes Ancient Love tourists in Guilin as experimental samples. The author conducted a questionnaire survey in Guilin Ancient Love venue in

Independent Variables Dependent Variables

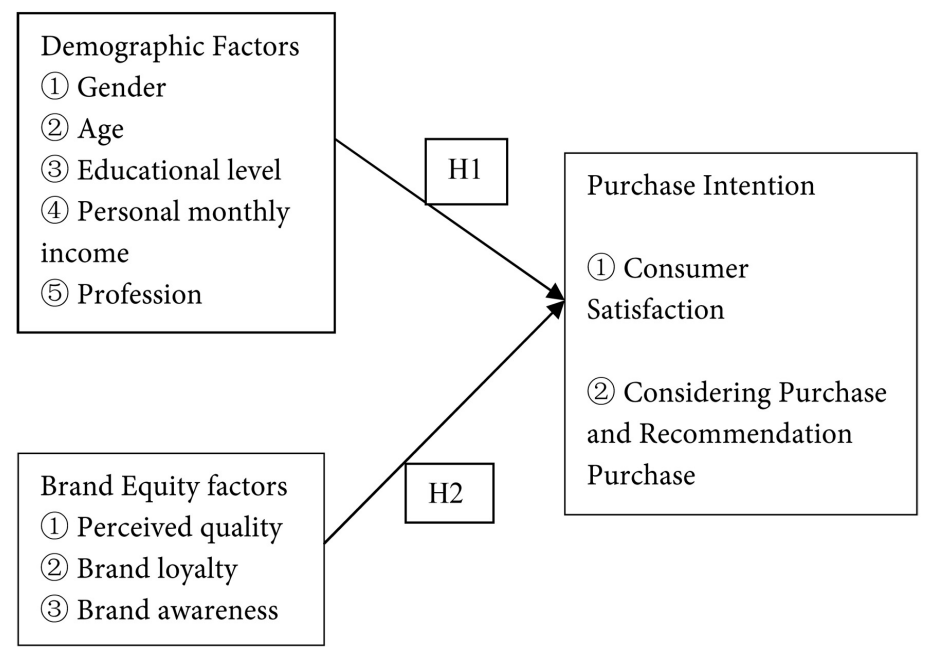

Figure 1. Researches conceptual framework source: authors, adopted from various sources. 
Yangshuo. Our sample collection time is from October 2019 to December 2019, during which there are two major festivals, National Day and Christmas, The large number of tourists facilitates the sample collection.

Due to the uncertainty of the number of consumers who came to watch the Ancient Love of Guilin, the uncertain sample size formula of Cochran (1977) was adopted to calculate the sample size to be tested.

$$
n_{0}=\frac{Z^{2} \times p \times(1-p)}{e^{2}}
$$

Source: W. G. Cochran, Representative sample for proportions in large populations.

$n_{0}$ - The sample size.

$Z^{2}$-The abscissa of the normal curve that cuts off an area $\alpha$ at the tails.

$e$-The acceptable sampling error.

$p$-The estimated proportion of an attribute that is present in the population.

Thus, When $Z=1.96, p=0.5, e=0.05$ using the above formula, the sample size to study is:

$$
n_{0}=\frac{1.96^{2} \times 0.5 \times(1-0.5)}{0.05^{2}}=384 \approx 400
$$

The sample size is 384 . However, for easy to collect and process the data, the researcher collect data from 400 samples.

The author adopts the principles of on-site distribution and on-site recovery. In order to stimulate the desire of the respondents to fill in the questionnaire, the respondents will be given a small gift before filling in the questionnaire. In order to ensure the validity of questionnaire recovery, the author will one month to distribute questionnaires, and a total of 400 valid questionnaires were collected in this study.

\subsection{Sampling}

The purpose of targeted sampling is to collect the ideas and opinions of the subjects more purposefully, and the collected data can provide more information for research.

\subsection{Data Collection and Data Analysis}

Questionnaire is a simple and efficient way to collect primary data, which is one of research methods commonly used by management scholars. The questions in the survey questionnaire are developed from the information based on the independent variables, and relationships between independent variables and variables in the study.

Yoo et al. (2001) brand Equity scale was adopted to measure brand equity, which was divided into three dimensions: brand awareness, Perceived quality, Brand loyalty. According to Etzel et al. (2006), the size of demographic factors is divided into gender, age, educational level and personal monthly income. 
The questionnaire will be dividing into three parts: the first part is restrictive condition; the second part is the demographic factors related to purchase intention. Open-ended questions based on basic personal information, such as gender, age, educational level, personal monthly income and profession. In the third part, likert five-level scale (1932) is used to measure the relationship between independent variables and dependent variables.

After finish the first draft of the questionnaire design, professor invited five is engaged in the management research try to forecast, Item Objective Congruence (IOC) according to the opinions of the respondents and other explanation after completed the formal questionnaire. In order to further improve the questionnaire and test the reliability of the questionnaire, this study conducted a reliability test on the recovered samples through a trial survey. Tests were conducted by random sampling, and consumers who have watched the performances of Guilin's ancient love performances are survey samples. The total number of samples surveyed was 30 , including 18 female consumers and 12 male consumers. The age group was between 20 and 50 years old. 30 questionnaires were placed and 30 valid questionnaires were returned. Therefore, the reliability test is finally carried out on the research samples. A Cronbach's alpha score of 0.964 was achieved (see Table 3 below), which is close to 1, indicating that the variables and the overall credibility of the questionnaire are relatively high. The value of KMO and Bartlett's Test are 0.962, and the significance of the spherical test is also less than 0.05 , so the questionnaire has good structural validity (see Table 4 below).

This paper analyzes the factors influencing the purchase intention of tourism performing arts brand consumers and calculates the results. Descriptive statistical analysis (frequency, percentage and average) is used to describe the overall characteristics of consumer demographics in the primary data collected, and $\mathrm{X}$ and SD are used to analyze which factor is important among the influencing factors of consumers' purchase intention. $T$ test and other inference statistical methods were used to find out the relationship between independent variables and dependent variables, and then one-way ANOVA was used to compare the

Table 3. Reliability test result (total).

\begin{tabular}{cc}
\hline \multicolumn{2}{c}{ Reliability Statistics } \\
\hline Reliability Statistics & N of Items \\
0.964 & 54 \\
\hline
\end{tabular}

Table 4. KMO and bartlett's test (total).

\begin{tabular}{lcc}
\hline \multicolumn{2}{c}{ Kaiser-Meyer-Olkin Measure of Sampling Adequacy. } & 0.962 \\
& Approx. Chi-Square & 9064.867 \\
Bartlett's Test of Sphericity & df & 1378 \\
& Sig. & 0.00 \\
\hline
\end{tabular}


difference of the influence of different factors in the population variables on the dependent variables. Finally, the linear regression method is used to test the hypothesis, such as sig $<0.05$. This proves that the hypothesis is valid.

\section{Finding}

\subsection{Demographic Characteristic of Respondents}

Descriptive statistics classify the basic information of consumers who fill in questionnaires and calculate their frequency and proportion. This study mainly includes gender, age, education level, monthly income and other characteristics, so that you can have an intuitive and comprehensive understanding of the sample. The results are in Table 5.

Table 5. Description of the demographic characteristics of the interviewees.

\begin{tabular}{|c|c|c|c|}
\hline $\begin{array}{l}\text { Demographic } \\
\text { feature }\end{array}$ & Content & Numbers & Proportion \\
\hline \multirow{2}{*}{ Gender } & Female & 232 & $58 \%$ \\
\hline & Male & 168 & $42 \%$ \\
\hline \multirow{6}{*}{ Aged } & Lower than 20 & 37 & $9.3 \%$ \\
\hline & $21-30$ & 83 & $20.8 \%$ \\
\hline & $31-40$ & 86 & $21.5 \%$ \\
\hline & $41-50$ & 67 & $16.8 \%$ \\
\hline & $51-60$ & 84 & $21 \%$ \\
\hline & More than 60 & 43 & $10.8 \%$ \\
\hline \multirow{6}{*}{ Income } & less $1000 \mathrm{RMB}$ & 35 & $8.8 \%$ \\
\hline & $1000-2000 \mathrm{RMB}$ & 31 & $7.7 \%$ \\
\hline & $2001-3000 \mathrm{RMB}$ & 75 & $18.8 \%$ \\
\hline & $3001-4000 \mathrm{RMB}$ & 71 & $17.8 \%$ \\
\hline & 4001 - $5000 \mathrm{RMB}$ & 128 & $32 \%$ \\
\hline & More than $5000 \mathrm{RMB}$ & 60 & $15.0 \%$ \\
\hline \multirow{4}{*}{ Educational } & High School/Vocational & 67 & $16.8 \%$ \\
\hline & Undergraduate diploma & 149 & $37.3 \%$ \\
\hline & Master's Degree & 138 & $34.5 \%$ \\
\hline & Above Master's Degree & 46 & $11.5 \%$ \\
\hline \multirow{6}{*}{ Profession } & Students & 41 & $10.3 \%$ \\
\hline & $\begin{array}{l}\text { Government and public } \\
\text { institutions working staff }\end{array}$ & 83 & $20.8 \%$ \\
\hline & $\begin{array}{c}\text { Social organizations } \\
\text { working staff }\end{array}$ & 90 & $22.5 \%$ \\
\hline & Enterprise staff & 69 & $17.3 \%$ \\
\hline & Individual practitioners & 82 & $20.5 \%$ \\
\hline & Others & 35 & $8.8 \%$ \\
\hline
\end{tabular}


From Table 5 seen that 232 (58\%) female respondents in this survey are mainly aged between 31 to 40 (21.5\%), Undergraduate diploma 149 account for $37.3 \%$, Social organizations working staff $(22.5 \%)$, and their incomes are relatively average between 4000 and 5000 yuan (32\%). In general, the population distribution of respondents is wide and the proportion is relatively average. The results of the questionnaire survey can initially reflect the overall situation of the society.

\subsection{Descriptive Analysis Results}

The researchers asked consumers for their feedback on all relevant factors of tourism performing arts, including brand entity (brand awareness, perceived quality, brand loyalty) and consumers' purchase intention, and agreed on a scale from 1 (strongly disagree) to 5 (strongly agree) for each relevant factor by selecting the questions provided. Since the five-point scale is adopted, its mean value is $2.61-4.20$, indicating that the level of identity affects consumers' purchase intention of tourism performing arts and related factors. Brand entity is divided into three dimensions: brand awareness, perceived quality and brand loyalty. Brand awareness consists of eight questions. The average of all the questions ranged from 3.11 to 4.20 , indicating a consistent level of recognition of tourism performing arts brands. The highest level of consistency was brand advertising has an impact on your recall of the brand, with a mean of 4.01 and S.D. 99. The lowest was brand culture with an average of 3.27. S.D. was 1.352. The highest recognition level of this factor is the perceived value of the first question, with an average value of 3.92, S.D. is 0.84 . There are 6 questions in the brand loyalty questionnaire. The mean values of all the questions ranged between 2.61 3.40 and $3.41-4.20$, indicating a consistent level of brand loyalty to tourism performing arts.

\subsection{Hypothesis Testing}

The significance variables of independent and dependent variables were tested using a linear regression method. Test this hypothesis by comparing the values of the sig. 0.00 is the best, sig. 0.05 indicate that these two factors are unrelated. The significance of each variable to the dependent variable is analyzed in detail to analyze the specific factors that affect consumers' purchase intention.

Table 6 tells us that $\mathrm{R}$ is $71.4 \%$, which means that consumers' purchase intention of tourism performing arts products can be explained by brand entities (brand awareness, perceived quality and brand loyalty). The value of the adjusted $\mathrm{R}$ square is $71.2 \%$. Due to the number of observations, the value of the adjusted $\mathrm{R}$ square is closer to the value of the adjusted $\mathrm{R}$ square, which is very large

Table 6. Result of R square between independent variable and purchase intention.

\begin{tabular}{ccccc}
\hline Model & $\mathrm{R}$ & R Square & Adjusted R Square & Std. Error of the Estimate \\
\hline 1 & $0.807 \mathrm{a}$ & 0.714 & 0.712 & 0.47889 \\
\hline
\end{tabular}


compared to the number of predictors.

From Table 7, P value is less than 0.05. Let's assume that $\mathrm{H} 1$ and $\mathrm{H} 2$ are both acceptable. Thus, it influences consumers' brand entity (brand awareness, perceived quality and brand loyalty) and consumers' purchase intention of tourism performing arts.

In this study, we know from the measurement results $\mathrm{H} 1, \mathrm{H} 2$ are accepted, Demographic factors, brand equity has a significant impact on consumers' purchase intentions. Among the demographic factors, the sig value of the income factor is 0.584 , and the sig value of the occupation is 0.495 . The values of the two factors are both greater than 0.05 , indicating that the two factors have little influence on the purchase intention. In variable brand equity, the sig values of brand awareness, brand loyalty and Perceived quality are 0.00 . This indicates that brand equity has a significant impact on consumers' purchase intention (see Table 8 below).

Table 7. ANOVA analysis.

\begin{tabular}{ccccccc}
\hline Model & & Sum of Squares & df & Mean Square & F & Sig. \\
\hline \multirow{2}{*}{1} & Regression & 130.103 & 5 & 26.021 & 234.492 & $0.000 \mathrm{~b}$ \\
& Residual & 44.275 & 399 & 0.111 & & \\
& Total & 174.379 & 404 & & & \\
\hline
\end{tabular}

Table 8. Research hypothesis test results.

\begin{tabular}{|c|c|c|}
\hline Hypothesis & Sig value & Conclusion \\
\hline $\begin{array}{l}\text { H1: There is a significant relationship between the demographic } \\
\text { factors and consumers' purchase intention. }\end{array}$ & Sig $=0.000$. & Accepted \\
\hline $\begin{array}{l}\text { H1a: There is a significant relationship between the gender and } \\
\text { consumers' purchase intention. }\end{array}$ & Sig $=0.000$ & Accepted \\
\hline $\begin{array}{l}\text { H1b: There is a significant relationship between the age and } \\
\text { consumers' purchase intention. }\end{array}$ & Sig $=0.000$ & Accepted \\
\hline $\begin{array}{l}\text { H1c: There is a significant relationship between the education and } \\
\text { consumers' purchase intention. }\end{array}$ & Sig $=0.000$ & Accepted \\
\hline $\begin{array}{l}\text { H1d: There is a no significant relationship between the income and } \\
\text { consumers' purchase intention. }\end{array}$ & Sig $=0.584$ & Rejected \\
\hline $\begin{array}{l}\text { H1e: There is a significant relationship between the profession and } \\
\text { consumers' purchase intention. }\end{array}$ & Sig $=0.495$ & Rejected \\
\hline $\begin{array}{l}\text { H2: There is a significant relationship between brand equity and } \\
\text { consumers' purchase intention of tourism performing arts. }\end{array}$ & $\operatorname{sig}=0.000$ & Accepted \\
\hline $\begin{array}{l}\text { H2a: There is a significant relationship between Perceived quality } \\
\text { and consumers' purchase intention of tourism performing arts. }\end{array}$ & Sig $=0.000$ & Accepted \\
\hline $\begin{array}{l}\text { H2b: There is a significant relationship between brand loyalty and } \\
\text { consumers' purchase intention of tourism performing arts. }\end{array}$ & Sig $=0.000$ & Accepted \\
\hline $\begin{array}{l}\text { H2c: There is a significant relationship between brand awareness } \\
\text { and consumers' purchase intention of tourism performing arts. }\end{array}$ & Sig $=0.000$ & Accepted \\
\hline
\end{tabular}




\section{Conclusion}

This result is supported in part by previous research. In this study, the component of brand equity (brand awareness, perceived quality and brand loyalty) has a significant impact on the purchase intention of tourism performing arts consumers. This means that consumers' purchase intention of tourism performing arts can be explained by brand awareness, perceived quality and brand loyalty. Sig value is less than 0.05 . Let's assume that $\mathrm{H} 1$ and $\mathrm{H} 2$ are both acceptable, thus influencing consumers' purchase intention of tourism performing arts brand products. The $\mathrm{P}$ values of brand awareness coefficient, perceived quality coefficient and brand loyalty coefficient are less than 0.05 , which affect consumers' purchase intention. The higher the brand awareness, the stronger purchase intention of consumers (Rossiter \& Percy, 1987). Brand loyalty is the highest, indicating that brand loyalty is an important factor influencing consumers' purchase intention of tourism performing arts (Vazquez \& Iglesias, 2002).

\section{Research Contribution}

There are few researches on tourism performing arts, so this research has contribution about tourism performing arts for Guilin. It can understand which kind of people have a strong demand for Guilin's tourism performing arts, and provide better suggestions for enterprises. We can find out the interests and demand points of consumers, improve the competitiveness of enterprises, and promote the coordinated growth of local tourism, cultural industry and regional economy.

\section{Recommendations for Further Research}

Tourism performing arts is a new subject in the study of cultural industry. From the perspective of brand research, there are few researches on tourism performing arts. In China, cultural industry has boomed, with many venues set up but no brand registration or chain operation. In such a market environment, how to make use of the main resources of the folk music and culture industry to create a national performance brand reflecting the local cultural characteristics, and how to improve the combination of the market competitiveness of the brand and consumer demand, is the focus of future research. In this study, we studied the factors affecting consumers' purchase intention, but due to the short sampling time, the respondents had limitations; Brand surveys do not necessarily reflect the whole picture; Although this study draws on the literature of many scholars, it mainly studies consumers' purchase intention from the perspective of brand awareness, which is not in-depth enough and needs further study. However, researchers believe that folk music, as a time-space art has a solid humanistic foundation, which can be inherited through tourism and other industries, so that the world can understand China and bring Chinese national culture to the world. 


\section{Conflicts of Interest}

The authors declare no conflicts of interest regarding the publication of this paper.

\section{References}

Aaker, D. A. (2009). Managing Brand Equity (pp. 74-75). New York, NY: Simon \& Schuster Inc., The Free Press.

Alhadid, A. Y. (2014). The Impact of Social Media Marketing on Brand Equity: An Empirical Study on Mobile Service Providers in Jordan. Review of Integrative Business and Economics Research, 3, 315-326.

China National Tourism Administration (2017). China Tourism Statistics Bulletin. https://mtop.aizhan.com/48110.html

China Tourism Performance Market (2019). Analysis of the Market Development Status and Trend of China's Tourism and Performing Arts Industry in 2019. https://www.qianzhan.com/analyst/detail/220/200114-e8940917.html

Cochran, W. G. (1977). Sampling Techniques (3rd ed.). Hoboken, HJ: John Wiley \& Sons.

Etzel, M. J., Walker, W. J., \& Stanton, W. J. (2006). Marketing (12th ed.). Boston, MA: McGraw-Hill.

Fouladivanda, F., Pashandi, M. A., Hooman, A., \& Khanmohammadi, Z. (2013). The Effect of Brand Equity on Consumer Buying Behavior in Term of FMCG in Iran. Interdisciplinary Journal of Contemporary Research in Business, 4, 945-995.

Gong, M. H. (2011). Tourism Anthropology (p. 15). Beijing: Tourism Education Press.

Pan \& Li (2018). Consumer Behavior. Beijing: Beijing Institute of Technology Press.

Rossiter, J. R., \& Percy, L. (1987) Advertising and Promotion Management. New York, NY: McGraw-Hill Series in Marketing.

Keller, K. L. (2001). Builder Customer-Based Brand Equity. Journal of Marketing, 10, 14-19.

Kotler, P. (2002). Marketing Management (11th ed.). Upper Saddle River, NJ: Prentice Hall.

Meena, R., \& Vishnu, S. (2018). Building Brand Equity in Retail Banks: the Case of Trinidad and Tobago. International Journal of Bank Marketing, 32, 64-92.

Song, J., \& Li, G. H. (2019). Emotional Marketing of Ethnic Cultural Tourism Performing Arts Products: A Case Study of Zuo Mei of Dong Minority. Journal of Hubei University of Arts and Science, 40, 39-44.

Vázquez, R., A. del Río, B., \& Iglesias, V. (2002) Consumer-Based Brand Equity: Development and Validation of a Measurement Instrument. Journal of Marketing Management, 18, 24-78. https://doi.org/10.1362/0267257022775882

Wu, C. Z. (2012). Development Status and Trend of Historical and Cultural Tourism in Western Countries. Human Geography, 19, 62-66.

Yang, W. W., \& Liu, X. (2000). The Influence of Brand Cognition on Consumer Buying Behavior. Commercial Research, No. 3, 158-162.

Yoo, B., Donthu, N., \& Lee, S. (2001). An Examination of Selected Marketing Mix Elements and Brand Equity. Journal of the Academy of Marketing Science, 28, Article No. 195. https://doi.org/10.1177/0092070300282002 